\title{
Wing morphology is linked to stable isotope composition of nitrogen and carbon in ground beetles (Coleoptera: Carabidae)
}

\author{
Marcin ZALEWSKI ${ }^{1}$, Dorota DUDEK-GODEAU ${ }^{2}$, Alexei V. TIUNOV ${ }^{3}$, Jean-François GODEAU ${ }^{4}$, \\ YutaKa OKUZAKI ${ }^{5}$, Hiroshi IKEDA ${ }^{6}$, PaWEe SIENKIEWICZ ${ }^{7}$ and Werner ULRICH ${ }^{8}$ \\ ${ }^{1}$ Museum and Institute of Zoology, Polish Academy of Sciences, Wilcza 64, 00-679 Warsaw, Poland; \\ e-mail: zlewek@yahoo.com \\ ${ }^{2}$ Al. Armii Krajowej 32/19, 05-800 Pruszków, Poland; e-mail: porrkana@wp.pl \\ ${ }^{3}$ Institute of Ecology and Evolution, Russian Academy of Sciences, Leninsky Prospect 33, 119071, Moscow, Russia; \\ e-mail: a_tiunov@mail.ru \\ ${ }^{4}$ Cardinal Stefan Wyszynski University, Faculty of Biology and Environmental Sciences, Dewajtis 5, 01-815 Warsaw, Poland; \\ e-mail: jfgodeau@gmail.com \\ ${ }^{5}$ Field Science Center for Northern Biosphere, Hokkaido University, North 11, West 10, Sapporo, 060-0811, Japan; \\ e-mail: yutaka@fsc.hokudai.ac.jp \\ ${ }^{6}$ Faculty of Agricultural and Life Science, Hirosaki University, Bunkyo-cho, Hirosaki, Aomori 036-8561, Japan; \\ e-mail: hikeda@hirosaki-u.ac.jp \\ ${ }^{7}$ Department of Entomology and Environmental Protection, Poznań University of Life Sciences, Dąbrowskiego 159, 60-594 Poznań, \\ Poland; e-mail: carabus@up.poznan.pl \\ ${ }^{8}$ Nicolaus Copernicus University in Toruń, Chair of Ecology and Biogeography, Lwowska 1, 87-100 Toruń, Poland; \\ e-mail: ulrichw@umk.pl
}

Key words. Coleoptera, Carabidae, mobility, island, niche width, stable isotopes, trophic level, wing dimorphism, $\delta^{15} \mathrm{~N}, \delta^{13} \mathrm{C}$

\begin{abstract}
As movement is expensive in terms of energy required, mobile animals might have to utilize more energy rich resources than less mobile animals. As mobile animals are possibly more effective foragers we hypothesize a positive correlation between mobility and trophic niche width. We address this link using information on the trophic level of 35 winged, wingless and wing dimorphic species of ground beetles studied on 18 lake islands and at two mainland sites in northern Poland. Trophic analyses using stable isotope values $\left(\delta^{15} \mathrm{~N}, \delta^{13} \mathrm{C}\right)$ revealed that winged individuals of wing dimorphic species are characterized by broader isotopic niches than wingless individuals. Macropterous species are characterized by depleted $\delta^{13} \mathrm{C}$ values, which can be interpreted in terms of lipid-rich prey selection. Wing dimorphic species are characterized by higher trophic levels, as inferred from $\delta^{15} \mathrm{~N}$ values, than winged species. Numbers of islands colonized by particular species were not correlated with $\delta^{15} \mathrm{~N}$ values, $\delta^{13} \mathrm{C}$ values or isotopic niche width. Our results point to a relationship between diet and wing morphology in ground beetles.
\end{abstract}

\section{INTRODUCTION}

The ability of animals to move is a key component of many important activities like foraging, reproduction or predator avoidance (Begon et al., 2006). In particular, it determines the ability to disperse and influences energy budgets that affect other life history traits (e.g. Dingle, 1978; Roff, 1990; Guerra, 2011). While movement is expensive in terms of energy (Zera \& Denno, 1997; Combes \& Dudley, 2009; Bonte et al., 2012), mobile animals might utilize different resources than less mobile animals. In addition, the ability to use distant and diverse food resources might correlate with the degree of polyphagy (Real \& Caraco, 1986), or alternatively less mobile animals might be dependent on local, often poor quality resources, whereas mobile animals can search for and select high quality food items; so mobile animals might be characterized by a narrower trophic niche. In consequence, trophic niche breadth and possibly trophic level might be linked to their ability to move. Such differences should be observable both between individuals of the same species with different mobilities and between species, although this hypothesis has so far not been verified. Here, we address the link between wing morphology of ground beetles and resource use at both intra- and interspecific levels.

Ability to move and trophic level are not easily measured traits and appropriate data are available for only a small number of taxa. In this respect probably the best studied are ground beetles (Kotze et al., 2011). While wing morphology and dispersal ability in Carabidae are not linked in a simple way due to e.g. autolysis of flight muscles (Den Boer et al., 1980, Desender, 2000), beetles can be unequivocally classified according to wing morphology into winged, wingless and wing dimorphic species (Den Boer et al., 1980).

In contrast to wing morphology, trophic levels are difficult to estimate in carabids and major compilations rely on feeding experiments, gut content analysis and field observations (Hengeveld, 1980; Harwood et al., 2001; Juen \& Traugott, 2006). Stable isotope analysis promises a better 
assessment of trophic level and diet type (Layman et al., 2007; Martinez del Rio et al., 2009; Boecklen et al., 2011). The carbon isotope value of body tissues $\left(\delta^{13} \mathrm{C}\right.$, reflecting the ${ }^{13} \mathrm{C} /{ }^{12} \mathrm{C}$ value) is approximately stable across trophic levels but depends on resource type and habitat, while the nitrogen isotope value $\left(\delta^{15} \mathrm{~N}\right.$, reflecting the ${ }^{15} \mathrm{~N} /{ }^{14} \mathrm{~N}$ value $)$ increases in insects by about $2.5 \%$ per trophic level (McCutchan et al., 2003; Vanderklift \& Ponsard, 2003; Ikeda et al., 2010) and thus indicates the relative position of an individual within its food chain. Hence variation in $\delta^{13} \mathrm{C}$ and $\delta^{15} \mathrm{~N}$ values delineates the "isotopic niche" that is distinct from, but in many circumstances should align closely with, the actual trophic niche (Newsome et al., 2007; Layman et al., 2012). In ground beetles, stable isotope analysis has already proven to be a powerful tool for inferring trophic differences both between species and between individuals of the same species (e.g. Okuzaki et al., 2009, 2010; Sasakawa et al., 2010). In particular, this method has revealed that carabids feed on different diets ranging from living and decomposing plant material to epigeic predatory arthropods across more than three trophic levels (Zalewski et al., 2014). Their broad spectrum of trophic preferences and the variation in their wing morphology, within and between species, make Carabidae a unique model for investigating the relationship between mobility and trophic position.

In particular wing dimorphic species (species is composed of winged and wingless individuals) provide an opportunity to analyse the relationship between mobility and trophic level. Winged individuals of wing dimorphic insects are more mobile than wingless individuals, even if they have already lost the ability for effective flight (Socha \& Zemek, 2003). As flight and development of wings are resource costly, winged beetles are expected to have higher energy requirements than their wingless counterparts (Bonte et al., 2012). In arthropods, predators can be lipid limited (Wilder et al., 2013) and might have to seek for lipid rich (i.e. energy rich) food. This should be mostly manifested in winged beetles. As lipids are ${ }^{13} \mathrm{C}$-depleted (Post et al., 2007, Tarroux et al., 2010), winged animals ought to be characterized by depleted $\delta^{13} \mathrm{C}$ values. In addition, the higher activity of winged individuals might lead to a more diversified diet due to their greater chances of encountering different types of prey. Consequently, winged individuals of dimorphic species might be expected to be more omnivorous. These patterns should be observable both within dimorphic species where both winged and wingless individuals exist and among species with different wing morphologies.

There have been several attempts to integrate food web theory into models of species spatial distribution and island biogeography (Holt, 2010; Gravel et al., 2011). These models predict a positive correlation between trophic niche breadth and individual home range in heterogeneous landscapes (Gravel et al., 2011). In ground beetles species spatial distributions are indeed connected to wing morphology (e.g. Den Boer, 1990; Gutierrez \& Menéndez, 1997; Zalewski \& Ulrich, 2006). Therefore, the prediction of
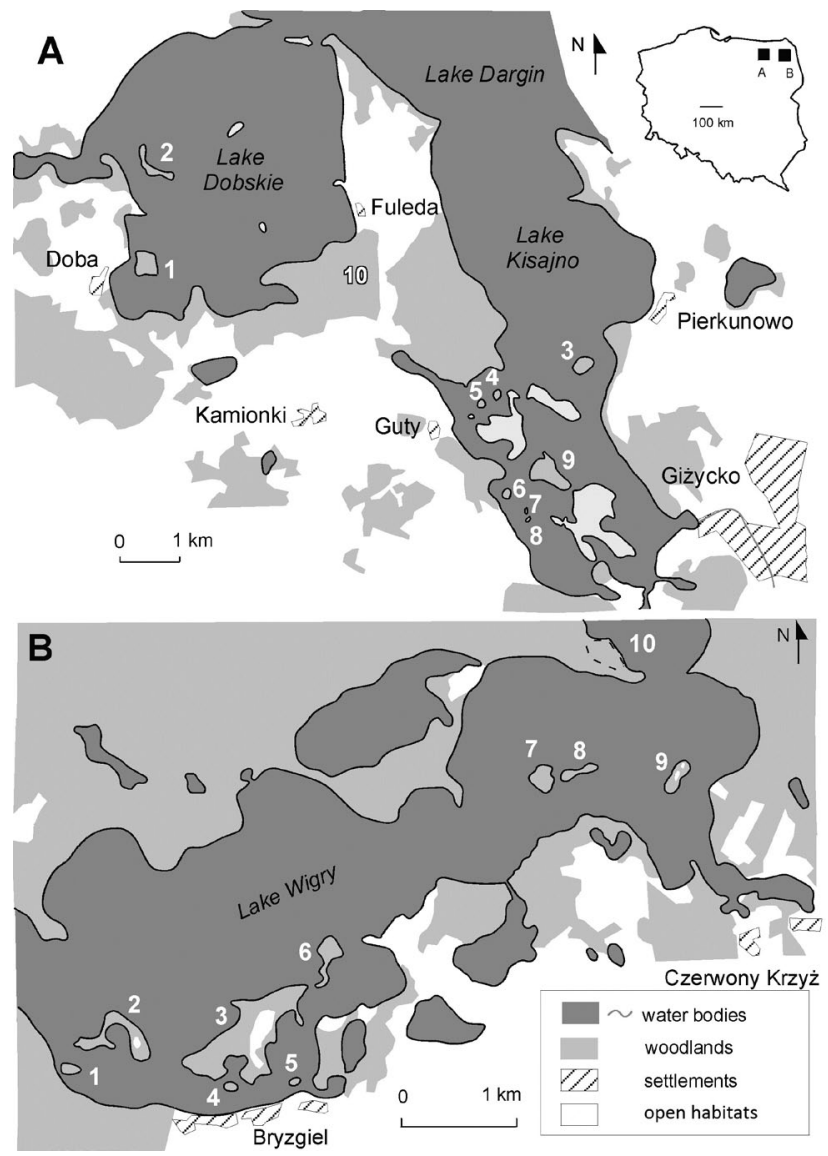

Fig. 1. Map showing the two archipelagos studied. A - Mamry Lake (complex of lakes: Dobskie, Kisajno and Dargin) and map of Poland (right upper corner); B - Wigry Lake.

Gravel et al. (2011) might also apply to the relationship between trophic niche width and distributions of carabids.

Stable isotope analysis can be used to test these predictions in detail. Below, we link trophic niche space, wing morphology and the spatial distributions of ground beetles to test for an unexplored relationship between key life history traits. We predict that (1) winged beetles are characterized by larger trophic niches than wingless beetles, and that (2) winged beetles are characterized by lower $\delta^{13} \mathrm{C}$ values than wingless beetles. We test these predictions within and between species.

\section{MATERIAL AND METHODS}

\section{Study sites and sampling}

We sampled carabid beetles on 18 islands and at two adjacent mainland sites (Fig. 1) in two lakes in NE Poland: Lake Mamry $\left(54^{\circ} 00^{\prime}-54^{\circ} 10^{\prime} \mathrm{N}, 21^{\circ} 30^{\prime}-21^{\circ} 52^{\prime} \mathrm{E}\right)$ and Lake Wigry $\left(54^{\circ} 00^{\prime}-54^{\circ} 05^{\prime} \mathrm{N}, 22^{\circ} 01^{\prime}-22^{\circ} 09^{\prime} \mathrm{E}\right)$. The islands varied in size (0.15-38.82 ha) and distance to the nearest mainland (30-375 m). In both archipelagos humid Alder (Alnion glutinosae) and LimeOak forests (Tilio-Carpinetum betuli) dominate. In addition, there were abandoned pastures on three of the islands in Lake Wigry (Arrhenatherion and Cynosurion alliances). All habitats on each island were sampled along a total of 27 transects. On each island and in each habitat we established transects composed of 10 pitfall traps $(0.51$ plastic mug, mouth diameter $120 \mathrm{~mm}$, plastic roof, filled with pure monoethylene glycol) set $10 \mathrm{~m}$ apart. The traps were emptied weekly and animals were preserved in $96 \%$ alco- 
hol. This procedure does not influence the isotopic composition of carbon and nitrogen in beetles (Zalewski et al., 2012), however some caution is necessary since similar procedures affected carbon signatures in some other animals (Tillberg et al., 2006). Emptied traps were refilled with fresh monoethylene glycol. Sampling was conducted over periods of four weeks in June and August 2010 , respectively. Wing morphology and species average body length was assessed using data in the literature (Den Boer et al., 1980, Lindroth \& Bangsholt, 1985, Hůrka, 1996) and in addition for the seven wing dimorphic species wing morphology was determined by visual inspection.

\section{Stable isotope analysis}

In total we determined the isotopic values of 1155 individual ground beetles belonging to 57 species (see Appendix 1) and the following analyses are based on 35 ground beetle species of which at least five individuals were analyzed. The stable isotope data used in this study was already published in Zalewski et al. (2014). In particular the present analyses include the results for 16 winged species (370 individuals), 11 wing dimorphic species (647 individuals) and 8 wingless species (90 individuals) (see Appendix 1). This sample contained 553 individuals belonging to 7 wing-dimorphic species (Agonum fuliginosum, Carabus granulatus, Notiophilus palustris, Agonum (Oxypselaphus) obscurus, Pterostichus melanarius, P. minor, P. strenuus) for which wing morphs were recorded and were used in comparisons of stable isotope composition between morphs of particular species.

Isotopic values were determined using the standard procedures fully described in Zalewski et al. (2014). Isotope values are expressed in delta (" $\delta$ ") units as a deviation from the international standards and recalculated in terms of parts per thousand (\%o), according to the formula: $\delta^{13} \mathrm{C}$ or $\delta^{15} \mathrm{~N}(\%)=\left(\mathrm{R}_{\text {sample }} / \mathrm{R}_{\text {standard }}-1\right)$ $\times 1000$, where $\mathrm{R}$ is the value of heavy/light isotope content for the element studied. The international standards were Pee Dee Belemnite for $\delta^{13} \mathrm{C}$ and atmospheric nitrogen for $\delta^{15} \mathrm{~N}$. To account for differences in isotopic baseline values recorded for different sampling sites, we collected litter samples along each trap line (in total 5 samples per line) in the middle of June and August 2010. Baseline samples were dried at $60^{\circ} \mathrm{C}$ for $48-70 \mathrm{~h}$ and analyzed following the methodology used for beetles. The carbon isotopic signature of the baseline was different for meadows and forested sites, but not for the different islands (Dudek-Godeau et al., in prep.), therefore the mean value of $\delta^{13} \mathrm{C}_{\text {litter }}$ was calculated for each of the three habitats sampled (alder and lime forests and meadows) and was used for baseline correction $\left(\delta^{13} \mathrm{C}_{\text {beetle }}=\delta^{13} \mathrm{C}_{\text {raw }}\right.$ beetle $-\delta^{13} \mathrm{C}_{\text {average litter in habitat }}$ ). Due to the high variability of $\delta^{15} \mathrm{~N}_{\text {litter }}$ values $($ mean $=-2.7, \mathrm{SD}=1.3, \mathrm{n}=135)$, the mean $\delta^{15} \mathrm{~N}$ was calculated for each trap line and used for the baseline correction $\left(\delta^{15} \mathrm{~N}_{\text {beetle }}=\delta^{15} \mathrm{~N}_{\text {raw beetle }}-\delta^{15} \mathrm{~N}_{\text {average litter on trapline }}\right)$. We note that there was only a single habitat on most islands and that the vast majority of species were recorded only in one habitat. This limited variability makes the inference of habitat specific trophic differences challenging. Therefore, we use habitat only for appropriate baseline correction but focus on trophic differences between islands. We further note that the use of single traps might introduce some degree of pseudoreplication as traps from a particular trap line might share common habitat specific isotope signals that would reduce intra-island variability in isotopic space. However, as all species will be affected similarly this possible bias should not affect the assessment of differences with respect to flight ability.

\section{Data analysis}

The standard ellipse area is proposed as a metric of isotopic niche width that is unbiased with respect to sample size, particularly for the Bayesian method, which accounts for the greater uncertainty associated with smaller sample sizes (Jackson et al. 2011). Estimates of the Bayesian standard ellipse area (SEA) were calculated using the package R, SIAR (Parnell et al., 2010). To statistically compare the size of ellipses for different categories we used the mean of SEA calculated based on 10,000 iterations. We calculated respective SEA's for all 35 species (at least five individuals analyzed) and related SEA's and trophic positions ( $\delta^{15} \mathrm{~N}$ and $\delta^{13} \mathrm{C}$ values) to flight ability using general linear modelling (co-variance analysis with body size as the continuous predictor, based either on all individuals or on species averages) and Tukey post hoc comparisons with orthogonal sums of squares and asymptotic error estimations as implemented in Statistica 7.0. The same individual-based linear model structure with body length as metric co-variate was also used to assess differences in isotopic ratios between islands, species and wing morphs. A critical point when using an individual based analysis might be the possible non-independence of data due to species membership. In a previous study (Zalewski et al., 2014) we demonstrated the high intraspecific variability in isotopic niche spaces that frequently exceeded the interspecific differences. Nevertheless, in order to account for this possible source of error we followed the approach of Ulrich et al. (2014) and reduced the error degrees of freedom (1099) to the total number of traps (270) in the individual based modelling. This approach should maximally limit the possible non-independence induced by trapping many individuals in the same trap.

Pearson correlation analysis was used to infer relationship between $\delta^{15} \mathrm{~N}, \delta^{13} \mathrm{C}$ and SEA values of species of ground beetles and the number of islands colonized.

\section{RESULTS}

General linear modelling revealed highly significant differences between populations from different islands $(\mathrm{P}<$ $0.0001)$ and between individuals of winged, wingless and dimorphic species $(\mathrm{P}<0.0001)$ with respect to $\delta^{15} \mathrm{~N}$ and $\delta^{13} \mathrm{C}$ values (Table 1 ). We also found highly significant island $\times$ flight ability interaction terms indicating that the

TABLE 1. General linear modelling (orthogonal sums of squares) for litter-corrected $\delta^{15} \mathrm{~N}$ and $\delta^{13} \mathrm{C}$ values depending on island and wing morphology as categorical and body size as a covariate. To account for the possible statistical non-independence of individuals from the same trap we reduced the error degrees of freedom to the total number of traps (270) instead of using the total number of individuals (1155). $\delta^{13} \mathrm{C}$ value: $\mathrm{r}^{2}=0.38, \mathrm{P}<0.001, \delta^{15} \mathrm{~N}$ value: $\mathrm{r}^{2}=0.65, \mathrm{P}<0.001$.

\begin{tabular}{lrrrc}
\hline Variable & SS & df & F & P \\
\hline Corrected $\delta^{13} \mathrm{C}$ & & & & \\
Constant & 863.7 & 1 & 1538.7 & $<0.0001$ \\
Island & 41.3 & 19 & 3.9 & $<0.0001$ \\
Flight ability & 61.8 & 2 & 55.1 & $<0.0001$ \\
Island $\times$ flight ability & 33.4 & 34 & 1.8 & 0.006 \\
Body size & 0.05 & 1 & 0.1 & $>0.50$ \\
Error & 616.9 & 270 & & \\
\hline Corrected $\delta^{15} \mathrm{~N}$ & & & & \\
Constant & 4903.2 & 1 & 2394.2 & $<0.0001$ \\
Island & 270.8 & 19 & 7.0 & $<0.0001$ \\
Flight ability & 46.1 & 2 & 11.2 & $<0.0001$ \\
Island $\times$ flight ability & 188.8 & 34 & 2.7 & $<0.0001$ \\
Body size & 8.7 & 1 & 4.3 & 0.05 \\
Error & 2250.7 & 270 & & \\
\hline
\end{tabular}



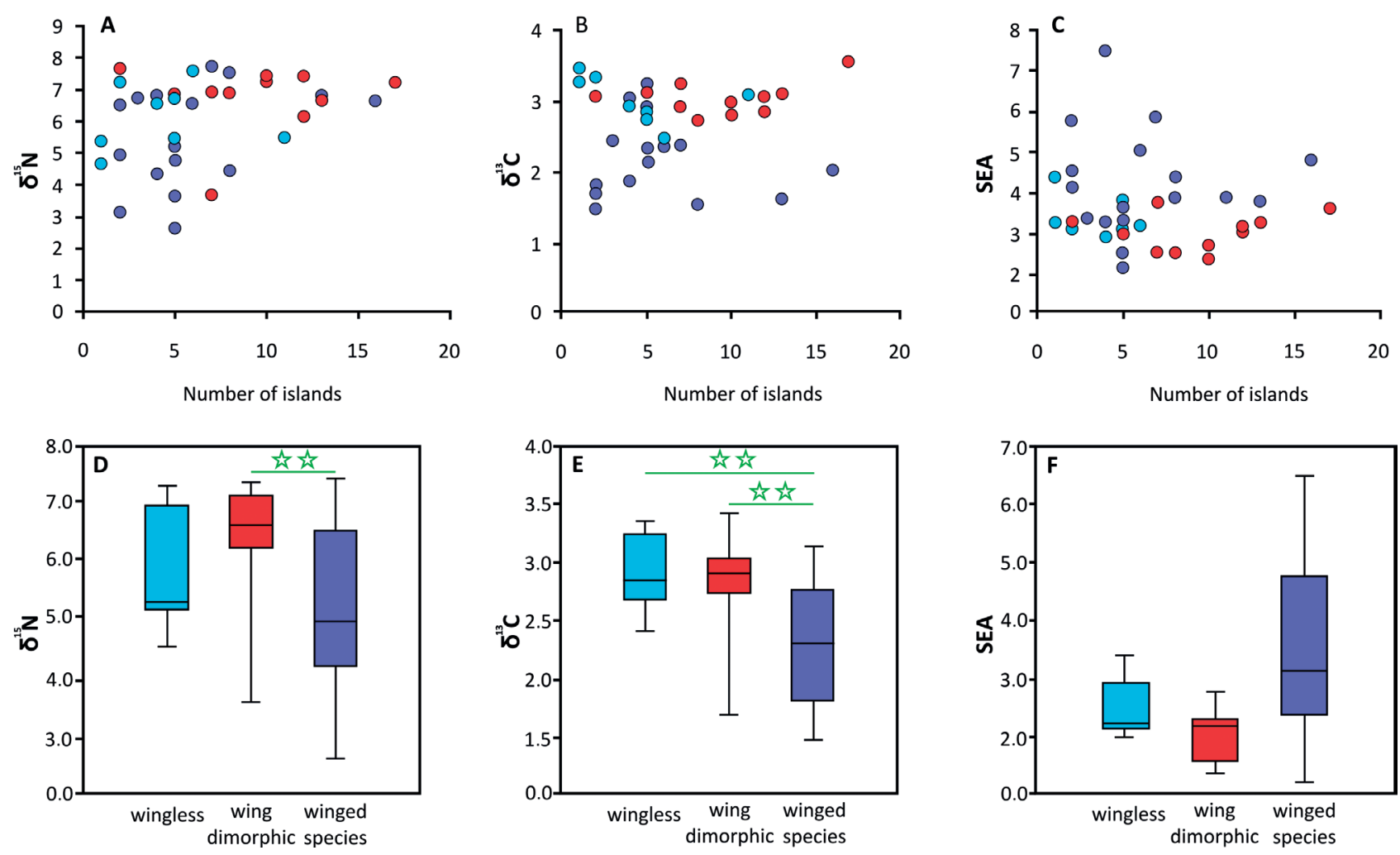

Fig. 2. $\delta^{15} \mathrm{~N}(\mathrm{~A}), \delta^{13} \mathrm{C}(\mathrm{B})$ and SEA (C) values for species of ground beetles were not related to island colonization (Pearson correlations: wingless species (blue dots), winged species (violet dots), wing dimorphic species (red dots): all $|\mathrm{r}|<0.2, \mathrm{P}>0.2$ ). Respective averages are presented in $\mathrm{D}, \mathrm{E}$ and $\mathrm{F}$ in the form of box-whiskers plots, which indicate the medians, $25-75$ percent quartiles (boxes) and minimum and maximum values (whiskers). Stars indicate significant $(\mathrm{P}<0.01)$ difference between sets of species (Tukey post hoc comparisons).

relationship between flight ability and stable isotope value is different across islands (Table 1). Tukey post hoc comparisons pointed to significant differences in $\delta^{15} \mathrm{~N}$ and $\delta^{13} \mathrm{C}$ values between the flight ability groups. Wingless and dimorphic species had significantly $(\mathrm{P}<0.01)$ higher $\delta^{13} \mathrm{C}$ values than winged species (Fig. 2E). With respect to $\delta^{15} \mathrm{~N}$, dimorphic species had significantly $(\mathrm{P}<0.01)$ higher values than winged species (Fig. 2D).

We did not find differences in isotopic niche breadth (SEAs) between the three flight ability groups (Table 2, all pair-wise comparisons: $\mathrm{P}>0.05$; Fig. $2 \mathrm{~F}$ ) and SEAs were not correlated with the number of islands colonized, total abundance or body length (Table 2, Fig. 2C). $\delta^{15} \mathrm{~N}$ and $\delta^{13} \mathrm{C}$ values were not significantly linked to the number of

TABLE 2. General linear modelling (orthogonal sums of squares) for standard ellipse areas (SEA) depending on wing morphology (categorical), trophic position (corrected $\delta^{13} \mathrm{C}$ and $\delta^{15} \mathrm{~N}$ ), number of sites colonized and total abundance (metrical): $\mathrm{N}=33 ; \mathrm{r}^{2}=$ $0.53, \mathrm{P}=0.008$.

\begin{tabular}{lrrrc}
\hline Variable & SS & df & F & P \\
\hline Body length & 0.03 & 1 & 0.02 & 0.86 \\
Abundance & 0.55 & 1 & 0.55 & 0.46 \\
Sites colonized & 0.15 & 1 & 0.15 & 0.70 \\
Flight ability & 7.61 & 2 & 3.67 & 0.04 \\
Trophic position & 6.09 & 2 & 2.94 & 0.07 \\
Error & 25.92 & 25 & & \\
\hline
\end{tabular}

islands colonized (Fig. 2A, B), although species that had colonized more than half of the islands studied occupied nearly exclusively higher trophic levels of $\delta^{15} \mathrm{~N}>5.0$ (Fig. 2A).

Intraspecific comparisons of wing morphs of seven wing dimorphic species (winged vs. wingless individuals) did not point to significant intraspecific differences with respect to $\delta^{15} \mathrm{~N}$ and $\delta^{13} \mathrm{C}$ values (except for $P$. melanarius). However, in three out of the four species for which we could calculate SEAs the macropterous individuals had larger SEAs (Table 3) than brachypterous individuals ( $p$ $<0.01)$.

\section{DISCUSSION}

Our study is apparently the first to compare trophic position and wing morphology in ground beetles. We found, based on their $\delta^{15} \mathrm{~N}$ values, that wing dimorphic species characteristically occupied higher trophic levels than winged species (Fig. 2D). The average $\delta^{13} \mathrm{C}$ values also differed between the three mobility groups (Table 1, Fig. 2E). Finally, we showed that isotopic niche space (SEA) of winged individuals is larger than that of wingless individuals in wing dimorphic species (Table 3).

Intraspecific variation in their ability to move might be common, but is usually difficult to measure (Bullock et al., 2002). Wing dimorphic insects, particularly ground beetles might serve as a suitable model (Roff, 1986). Contrary to our prediction, we found that in general macropterous in- 
TABLE 3. Average litter-corrected $\delta^{13} \mathrm{C}$ and $\delta^{15} \mathrm{~N}$ values ( \pm one standard error) and standard ellipse areas as approximations of the isotopic niche spaces (SEA) of wing dimorphic species. Due to sample size constraints it was only possible to estimate SEA for four species. Significant differences (t-test) between macropterous and brachypterous individuals (species): $* \mathrm{P}<0.05 ; * * \mathrm{P}<0.01 ; * * * \mathrm{P}<$ 0.001 . $\mathrm{N}$ - respective sample sizes. Note that $\delta$ values and SEA areas are measured in different units (value and eigenvalue scale) and thus are not directly comparable.

\begin{tabular}{|c|c|c|c|c|c|c|c|c|}
\hline \multirow{2}{*}{ Species } & \multicolumn{2}{|c|}{$\mathrm{N}$} & \multicolumn{2}{|c|}{$\mathrm{d}^{15} \mathrm{~N}$} & \multicolumn{2}{|c|}{$\mathrm{d}^{13} \mathrm{C}$} & \multicolumn{2}{|c|}{ SEA } \\
\hline & Macro. & Brach. & Macro. & Brach. & Macro. & Brach. & Macro. & Brach. \\
\hline Pterostichus melanarius & 55 & 81 & $7.54 \pm 0.17^{*}$ & $7.01 \pm 0.14^{*}$ & $3.37 \pm 0.11^{*}$ & $3.69 \pm 0.08^{*}$ & $3.71 \pm 0.29 * *$ & $1.97 \pm 0.08 * *$ \\
\hline Carabus granulatus & 22 & 123 & $6.34 \pm 0.13$ & $6.08 \pm 0.11$ & $2.99 \pm 0.12$ & $3.09 \pm 0.05$ & $2.71 \pm 0.22 * * *$ & $1.00 \pm 0.03 * * *$ \\
\hline Agonum fuliginosum & 23 & 75 & $7.44 \pm 0.25$ & $7.22 \pm 0.05$ & $2.92 \pm 0.14$ & $2.78 \pm 0.11$ & $1.99 \pm 0.19^{* * *}$ & $0.64 \pm 0.03 * * *$ \\
\hline Pterostichus strenuus & 26 & 35 & $6.66 \pm 0.24$ & $6.72 \pm 0.20$ & $3.07 \pm 0.11$ & $3.15 \pm 0.10$ & $1.68 \pm 0.13$ & $1.56 \pm 0.10$ \\
\hline Notiophilus palustris & 4 & 7 & $3.98 \pm 0.40$ & $3.46 \pm 0.36$ & $2.95 \pm 0.11$ & $2.98 \pm 0.13$ & & \\
\hline Agonum obscurum & 6 & 81 & $7.05 \pm 0.14$ & $7.46 \pm 0.26$ & $2.85 \pm 0.14$ & $2.85 \pm 0.09$ & & \\
\hline Pterostichus minor & 13 & 2 & $6.86 \pm 0.18$ & $6.67 \pm 0.31$ & $2.81 \pm 0.15$ & $2.63 \pm 0.52$ & & \\
\hline
\end{tabular}

dividuals did not differ from brachypterous individuals in terms of their carbon or nitrogen isotope composition. This indicates that both forms might on average occupy similar trophic levels and feed on similar sources of carbon. While the diet of different morphs of ground beetles has not been previously determined, studies on other wing dimorphic insects indicate that the different morphs use different resources. For instance, Dingle et al. (2009) record differences in the proboscis lengths of winged and wingless morphs of seed-feeding Hemiptera. In addition, in crickets the effectiveness of food assimilation might also differ between morphs (Mole \& Zera, 1993). Finally, Karpestam $\&$ Forsman (2013) record higher $\delta^{15} \mathrm{~N}$ values for winged morphs of a wing dimorphic grasshopper in one population and lower values in another. These authors interpreted their results in terms of the ability of winged grasshoppers to find and capture high quality food items.

Although $\delta^{15} \mathrm{~N}$ and $\delta^{13} \mathrm{C}$ values for the different wing morphs of carabids do not differ, morphs significantly differed with respect to isotopic niche breadth expressed in terms of SEA (Table 3). Apparently, macropterous beetles with potentially higher mobility and energy requirements obtain resources from different trophic levels and from different sources of carbon. This finding supports our first hypothesis that winged individuals of generalist predators should be more omnivorous (Wilder et al., 2013).

Broader isotopic niche spaces (SEAs) of winged individuals of dimorphic species (Table 3) are in line with recent theory that predicts that ecological generalists are highly mobile (Bonte et al., 2003; Billiard \& Lenormand, 2005; Ronce, 2007). Fig. 2F indicates a similar interpretation, although the recorded differences in niche space between wingless and winged species are statistically not significant (t-test: $\mathrm{P}=0.24$ and Table 2 ). Winged species were however characterized by strongly depleted $\delta^{13} \mathrm{C}$ values (Fig. 2E), as predicted by hypothesis 2. In this case, macropterous beetles might search for lipid-rich prey. As lipids are generally ${ }^{13} \mathrm{C}$ depleted (Post et al., 2007), mobile species (or possibly specimens of wing dimorphic species) should have comparably lower $\delta^{13} \mathrm{C}$ values. This interpretation is supported by data for Pterostichus melanarius, the only dimorphic species that was characterized by differ- ences in $\delta^{13} \mathrm{C}$ (Table 3 ). Our overall results are in line with winged species preferring more lipid rich prey.

Trophic niche width estimated using SEAs was not related to island occupancy by ground beetles (Table 2, Fig. 2C) which does not corroborate recent theoretical studies aimed at linking trophic ecology with island biogeography (Holt, 2010, Gravel et al., 2011). Indeed, differences between species in terms of the widths of their trophic niches might not be related to their being habitat generalists. Similarly the other finding that widespread species occupy higher trophic levels (Fig. 2A), while species with a restricted occurrence occupy all trophic levels, contradicts popular expectations. In particular Holt (2010) predicts a negative correlation between trophic level and home range due to the lower population densities of trophically high ranking species. Calcagno et al. (2011) states that if predators are constrained by the presence of their prey (see also Piechnik, 2013), which should restrict predator occurrences, then predators need to have high dispersal abilities in order to sustain viable populations. Apparently these models do not reveal the important constraints determining ground beetle spatial distributions.

Our results add to our knowledge of the relationship between two important ecological features of carabids: the trophic level of beetles and their wing morphology. However, there are some methodological pitfalls, which require further study. In particular, the $\delta^{15} \mathrm{~N}$ value is still only a proxy of the real trophic level within a food web (Martinez del Rio et al., 2009) and the difference in SEAs of winged and wingless individuals of wing dimorphic species can be biased due to errors in the baseline correction for animals that move from one habitat to another. However, as we tested different baseline corrections (Dudek-Godeau et al., in prep.), which gave qualitatively identical results, our findings indicate that in the system studied, which is composed of species of beetles with the whole range of mobility and feeding strategies, trophic characteristics expressed in terms of stable isotope composition of nitrogen and carbon are indeed linked to wing morphology. While these links are not always in accordance with theoretical predictions, areas of uncertainty identified in the present study could direct further research. 
ACKNOWLEDGEMENTS. We thank E. Zalewska, T. Plewka, P. Koperski, and I. Tayasu for technical help, and H. Hercman, M. Maruszkiewicz, P. Leśniak and P. Zawidzki for advice on isotopic analysis. D. Piechnik, V. Calcagno, D. Gravel, I. Hanski and two anonymous reviewers provided critical and helpful comments on earlier versions of this manuscript. H. Pearson and A.F.G. Dixon kindly improved our English. This work was supported by grants from the Polish Science Committee to WU (N N304 372839) and MZ (NN 304 354538). The present study was possible due to a Joint Usage / Research Grant from the Center for Ecological Research, Kyoto University.

\section{REFERENCES}

Begon M., Townsend C.R. \& Harper J.L. 2006: Ecology. From Individuals to Ecosystems. Blackwell, Oxford, $738 \mathrm{pp}$.

Billiard S. \& LeNORMAND T. 2005: Evolution of migration under kin selection and local adaptation. - Evolution 59: 13-23.

Boecklen W.J., Yarnes C.T., Cook B.A. \& James A.C. 2011: On the use of stable isotopes in trophic ecology. - Annu. Rev. Ecol. Evol. Syst. 42: 411-440.

Bonte D., Vandenbroecke N., Lens L. \& Maelfait J.-P. 2003: Low propensity for aerialdispersal in specialist spiders from fragmented landscapes. - Proc. R. Soc. Lond. (B) 270: 16011607.

Bonte D., Van Dyck H., Bullock J.M., Coulon A., Delgado M., Gibbs M., Lehouck V., Matthysen M., Mustin K., Saastamoinen M., Schtickzelle N., Stevens V.M., Vandewoestijne S., Baguette M., Barton K., Benton T.G., Chaput-Bardy A., Clobert J., Dytham C., Hovestadt T., Meier C.M., Palmer S.C.F., Turlure C. \& Travis J.M.J. 2012: Cost of dispersal. Biol. Rev. 85: 290-312.

Bullock J.M., Kenward R.E. \& Hails R. 2002: Dispersal Ecology. Blackwell, Oxford, $458 \mathrm{pp}$.

Calcagno V., Massol F., Mouquet N., Jarne P. \& David P. 2011: Constraints on food-chain length arising from regional metacommunity dynamics. - Proc. R. Soc. Lond. (B) 278: 3042 3049.

Combes S.A. \& Dudley R. 2009: Turbulence-driven instabilities limit insect flight performance. - Proc. Natn. Acad. Sci. U.S.A. 106: 9105-9108.

Den Boer P.J. 1970: On the significance of dispersal power for populations of carabid beetles (Coleoptera, Carabidae). - Oecologia 4: 1-28.

Den Boer P.J. 1990: Density limits and survival of local populations in 64 carabid species with different powers of dispersal. —J. Evol. Ecol. 3: 19-48.

Den Boer P.J., Van Huizen T.H.P., Den Boer-Dannje W. \& Den BIEMAN C.F.M. 1980: Wing polymorphism and dimorphism in ground beetles as stages in an evolutionary process. - Entomol. Gener. 6: 107-134.

Desender K. 2000: Flight muscle development and dispersal in the life cycle of carabid beetles: patterns and processes. - Entomologie 70: 13-31.

Dingle H. 1978: Evolution of Insect Migration and Diapause. Springer, Heidelberg, 284 pp.

Dingle H., Carroll S.P. \& Famula T.R. 2009: Influence of genetic architecture on contemporary local evolution in the soapberry bug, Jadera haematoloma: artificial selection on beak length. - J. Evol. Biol. 22: 2031-2040.

Gravel D., Massol F., Canard E., Mouillot D. \& Mouquet N. 2011: Trophic theory of island biogeography. - Ecol. Lett. 14: 1010-1016.

GuERRA P.A. 2011: Evaluating the life-history trade-off between dispersal capability and reproduction in wing dimorphic insects: a meta-analysis. — Biol. Rev. 86: 813-835.
Gutierrez D. \& Menéndez R. 1997: Patterns in the distribution, abundance and body size of carabid beetles (Coleoptera: Caraboidea) in relation to dispersal ability. $-J$. Biogeogr. 24: 903-914.

Harwood J.D., Phillips S.W., Sunderland K.D. \& Symondson W.O.C. 2001: Secondary predation: quantification of food chain errors in an aphid-spider-carabid system using monoclonal antibodies. - Mol. Ecol. 10: 2049-2058.

Hengeveld R. 1980: Polyphagy, oligophagy and food specialization in ground beetles (Coleoptera, Carabidae). - Neth. J. Zool. 30: 564-584.

Holt R.D. 2010: Towards a trophic island biogeography: reflections on the interface of island biogeography and food web ecology. In Losos J.B. \& Ricklefts R.E (eds): The Theory of Island Biogeography Revisited. Princeton University Press, Princeton, pp. 143-185.

Huberty A.F. \& Denno R.F. 2006: Consequences of nitrogen and phosphorus limitation for the performance of two planthoppers with divergent life-history strategies. _ Oecologia 149: 444455.

HưRKA K. 1996: Carabidae of the Czech and Slovak Republics. Kabourek, Zlín, 565 pp.

Ikeda H., Kubota K., Kagawa A. \& Sota T. 2010: Diverse diet compositions among harpaline ground beetle species revealed by mixing model analyses of stable isotope ratios. - Ecol. Entomol. 35: 307-316.

Jackson A.L., Inger R., Parnell A. \& Bearhop S. 2011: Comparing isotopic niche widths among and within communities: SIBER - Stable Isotope Bayesian Ellipses in R. - J. Anim. Ecol. 80: 595-602.

Juen A. \& Traugott M. 2006: Amplification facilitators and multiplex PCR: tools to overcome PCR-inhibition in DNA-gut content analysis of soil-living invertebrates. - Soil Biol. Biochem. 38: 1872-1879.

KARPESTAM E. \& Forsman A. 2013: Stable isotopes reveal dietary divergence between dispersal phenotypes in Tetrix subulata pygmy grasshoppers (Orthoptera: Tetrigidae). - Eur. J. Entomol. 110: 65-70.

Kotze J.D., Brandmayr P., Casale A., Dauffy-Richard E., Dekoninck W., Koivula M.J., Lövei G.L., Mossakowski D., Noordijk J., PaArmann W., Pizzolotto R., Saska P., Schwerk A., Serrano J., Szyszko J., Taboada A., Turin H., Venn S., Vermeulen R. \& Zetto T. 2011: Forty years of carabid beetle research in Europe - from taxonomy, biology, ecology and population studies to bioindication, habitat assessment and conservation. - Zookeys 100: 55-148.

Layman C.A., Araujo M.S., Boucek R., Hammerschlag-Peyer C.M., Harrison E., Jud Z.R., Matich P., Rosenblatt A.E., Vaudo J.J., Yeager L.A., Post D.M. \& Bearhop S. 2012: Applying stable isotopes to examine food-web structure: an overview of analytical tools. - Biol. Rev. 87: 545-562.

Lindroth C.H. \& Bangsholt F. 1985: The Carabidae (Coleoptera) of Fennoscandia and Denmark. Fauna Entomologica Skandinavica. Vol. 15, Part 1. E.J. Brill, Leiden, Kopenhagen, $225 \mathrm{pp}$.

Martinez del Rio C., Wolf N., Carleton S.A. \& Gannes L.Z. 2009: Isotopic ecology ten years after a call for more laboratory experiments. - Biol. Rev. 84: 91-111.

McCutchan J.H., Lewis W.M., Kendall C. \& McGrath C.C. 2003: Variation in trophic shift for stable isotope values of carbon, nitrogen, and sulfur. - Oikos 102: 378-390.

Mole S. \& Zera A.J. 1993: Differential allocation of resources underlies the dispersal reproduction trade-off in the wing-dimorphic cricket, Gryllus rubens. — Oecologia 93: 121-127. 
Newsome S.D., Martinez del Rio C., Bearhop S. \& Phillips D.L. 2007: A niche for isotopic ecology. - Front. Ecol. Environ. 5: 429-436.

OKuZaki Y., TAYasu I., OKuda N. \& Sota T. 2009: Vertical heterogeneity of a forest floor invertebrate food web as indicated by stable-isotope analysis. - Ecol. Res. 24: 1351-1359.

Okuzaki Y., Tayasu I., Okuda N. \& Sota T. 2010: Stable isotope analysis indicates trophic differences among forest floor carabids in Japan. - Entomol. Exp. Appl. 135: 263-270.

Parnell A.C., Inger R., Bearhop S. \& Jackson A.L. 2010: Source partitioning using stable isotopes: coping with too much variation. - PLoS ONE 5(3): e9672.

PIEChNiK D.A. 2013: Trophic levels colonize sequentially but effects of habitat size and quality are transient. - Acta Oecol. 47: $1-10$.

Post D.M., Layman C.A., Arrington D.A., Takimoto G., QuatTrochi J. \& Montana C.G. 2007: Getting to the fat of the matter: models, methods and assumptions for dealing with lipids in stable isotope analyses. - Oecologia 152: 179-189.

REAL L. \& CARACO T. 1986: Risk and foraging in stochastic environments. - Annu. Rev. Ecol. Syst. 17: 371-390.

RofF D.A. 1986: The evolution of wing dimorphism in insects. Evolution 40: 1009-1020.

Roff D.A. 1990: The evolution of flightlessness in insects. Ecol. Monogr. 60: 389-421.

Ronce O. 2007: How does it feel to be like a rolling stone? Ten questions about dispersal evolution. - Annu. Rev. Ecol. Evol. Syst. 38: 231-253.

Sasakana K., Ikeda H. \& Kubota T. 2010: Feeding ecology of granivorous carabid larvae: a stable isotope analysis. $-J$. Appl. Entomol. 134: 116-122.

SOCHA R. \& ZEMEK R. 2003: Wing morph-related differences in the walking pattern and dispersal in a flightless bug, Pyrrhocoris apterus (L.) (Heteroptera). - Oikos 100: 35-43.
Tarroux A., Ehrich D., Lecomte N., Jardine T.D., Bêty J. \& Berteaux D. 2010: Sensitivity of stable isotope mixing models to variation in isotopic ratios: evaluating consequences of lipid extraction. - Meth. Ecol. Evol. 1: 231-241.

Tillberg C.V., McCarthy D.P., Dolezal A.G. \& Suarez A.V. 2006: Measuring the trophic ecology of ants using stable isotopes. - Insectes Soc. 53: 65-69.

Ulrich W., Piwczyński M., Zaplata M. K., Winter S., Schaaf W. \& Fischer A. 2014: Small-scale spatial variability in phylogenetic community structure during early plant succession depends on soil properties. - Oecologia 175: 985-995.

VANDERKLIfT M.A. \& Ponsard S. 2003: Sources of variation in consumer-diet $\mathrm{d}^{15} \mathrm{~N}$ enrichment: a meta-analysis. — Oecologia 136: $169-182$.

Wilder S.M., Norris M., LeE R.W., Raubenheimer D. \& Simpson S.J. 2013: Arthropod food webs become increasingly lipid-limited at higher trophic levels. - Ecol. Lett. 16: 895-902.

ZaLewsKi M. \& Ulrich W. 2006: Dispersal as a key element of community structure: The case of ground beetles on lake islands. - Div. Distrib. 12: 767-775.

Zalewski M., Dudek D., Godeau J.F. \& Maruszkiewicz M. 2012: Stable isotopic research on ground beetles. Review of methods. - Baltic J. Coleopt. 12: 91-98.

Zalewski M., Dudek D., Tiunov A.V., Godeau J.-F., Okuzaki Y., IKedA H., Sienkiewicz P. \& UlRich W. 2014: High niche overlap in the stable isotope space of ground beetles. - Ann. Zool. Fenn. 51: 310-312.

Zera A.J. \& Denno R.F. 1997: Physiology and ecology of dispersal polymorphism in insects. - Annu. Rev. Entomol. 42: 207-231.

Received October 24, 2014; revised and accepted May 4, 2015 Prepublished online July 8, 2015

APPENDIX 1. A list of the species of ground beetles studied with wing morphology, body length, number of individuals studied, number of islands colonized, $\delta^{13} \mathrm{C}$ and $\delta^{15} \mathrm{~N}$ values along with their respective standard deviations. Stable isotope ratios are corrected by subtracting those of the litter (see text).

\begin{tabular}{|c|c|c|c|c|c|c|c|}
\hline Longname & $\begin{array}{l}\text { Morphology } \\
\text { of wings }\end{array}$ & $\begin{array}{l}\text { Body } \\
\text { lenght }\end{array}$ & $\begin{array}{c}\text { Number } \\
\text { of individuals }\end{array}$ & $\begin{array}{c}\text { Number } \\
\text { of colonized } \\
\text { islands }\end{array}$ & $\begin{array}{c}\delta^{13} \mathrm{C} \\
(\text { Mean } \pm \mathrm{SD})\end{array}$ & $\begin{array}{c}\delta^{15} \mathrm{~N} \\
(\text { Mean } \pm \text { SD })\end{array}$ & $\begin{array}{l}\text { Standard } \\
\text { Ellipse Area }\end{array}$ \\
\hline Agonum (Limodromus) assimile & winged & 11.0 & 18 & 6 & $2.36 \pm 0.95$ & $6.5 \pm 1.31$ & 4.02 \\
\hline Agonum (Oxypselaphus) obscurum & dimorphic & 5.4 & 87 & 12 & $2.85 \pm 0.66$ & $7.4 \pm 1.03$ & 2.17 \\
\hline Agonum (Platynus) livens & winged & 8.9 & 2 & 1 & $-0.26 \pm 0.20$ & $8.5 \pm 0.07$ & NA \\
\hline Agonum fuliginosum & dimorphic & 6.5 & 98 & 10 & $2.81 \pm 0.52$ & $7.3 \pm 1.02$ & 1.70 \\
\hline Agonum thoreyi & winged & 7.1 & 2 & 2 & $3.28 \pm 1.03$ & $8.2 \pm 0.80$ & NA \\
\hline Agonum viduum & winged & 7.9 & 1 & 1 & $3.10 \pm \mathrm{NA}$ & $6.1 \pm \mathrm{NA}$ & NA \\
\hline Amara brunnea & winged & 6.2 & 2 & 2 & $3.34 \pm 0.46$ & $5.8 \pm 0.27$ & NA \\
\hline Amara communis & winged & 6.9 & 25 & 5 & $2.91 \pm 0.79$ & $3.6 \pm 1.01$ & 2.61 \\
\hline Amara convexior & winged & 7.9 & 4 & 1 & $1.60 \pm 0.52$ & $3.9 \pm 0.72$ & NA \\
\hline Amara familiaris & winged & 6.4 & 1 & 1 & $-0.76 \pm \mathrm{NA}$ & $3.2 \pm \mathrm{NA}$ & NA \\
\hline Badister bullatus & winged & 5.4 & 5 & 4 & $2.84 \pm 0.58$ & $4.8 \pm 0.74$ & 2.38 \\
\hline Badister dilatatus & winged & 5.4 & 5 & 3 & $2.45 \pm 0.61$ & $6.7 \pm 2.10$ & 4.99 \\
\hline Badister lacertosus & winged & 5.9 & 14 & 5 & $3.24 \pm 0.43$ & $5.1 \pm 0.77$ & 1.43 \\
\hline Badister meridionalis & winged & 5.9 & 2 & 2 & $2.73 \pm 0.02$ & $5.7 \pm 0.44$ & NA \\
\hline Badister peltatus & winged & 4.8 & 3 & 2 & $1.44 \pm 0.96$ & $9.0 \pm 2.45$ & NA \\
\hline Badister sodalis & wingless & 4.2 & 6 & 5 & $2.75 \pm 0.77$ & $5.3 \pm 1.00$ & 2.77 \\
\hline Carabus cancellatus & wingless & 23.3 & 8 & 2 & $3.34 \pm 0.40$ & $7.2 \pm 1.18$ & 2.11 \\
\hline Carabus glabratus & wingless & 27.3 & 3 & 1 & $2.63 \pm 0.53$ & $5.2 \pm 0.99$ & NA \\
\hline Carabus granulatus & dimorphic & 19.8 & 145 & 12 & $3.07 \pm 0.55$ & $6.1 \pm 1.18$ & 2.03 \\
\hline Carabus hortensis & wingless & 24.8 & 11 & 4 & $2.93 \pm 0.57$ & $6.6 \pm 0.84$ & 1.97 \\
\hline
\end{tabular}


APPENDIX 1 (continued).

\begin{tabular}{|c|c|c|c|c|c|c|c|}
\hline Longname & $\begin{array}{l}\text { Morphology } \\
\text { of wings }\end{array}$ & $\begin{array}{l}\text { Body } \\
\text { lenght }\end{array}$ & $\begin{array}{c}\text { Number } \\
\text { of individuals }\end{array}$ & $\begin{array}{l}\text { Number } \\
\text { of colonized } \\
\text { islands }\end{array}$ & $\begin{array}{c}\delta^{13} \mathrm{C} \\
(\text { Mean } \pm \mathrm{SD})\end{array}$ & $\begin{array}{c}\delta^{15} \mathrm{~N} \\
(\mathrm{Mean} \pm \mathrm{SD})\end{array}$ & $\begin{array}{l}\text { Standard } \\
\text { Ellipse Area }\end{array}$ \\
\hline Carabus nemoralis & wingless & 22.4 & 18 & 7 & $3.09 \pm 0.78$ & $5.5 \pm 1.10$ & 2.89 \\
\hline Carabus violaceus & wingless & 28.5 & 6 & 1 & $3.46 \pm 0.45$ & $5.3 \pm 1.04$ & 2.28 \\
\hline Clivina fossor & dimorphic & 5.7 & 2 & 1 & $3.22 \pm 0.35$ & $10.6 \pm 0.05$ & NA \\
\hline Cychrus caraboides & wingless & 15.8 & 6 & 1 & $3.28 \pm 0.37$ & $4.7 \pm 1.65$ & 3.35 \\
\hline Dyschirius globosus & wingless & 2.4 & 1 & 1 & $2.64 \pm \mathrm{NA}$ & $11.2 \pm \mathrm{NA}$ & NA \\
\hline Elaphrus cupreus & winged & 7.9 & 1 & 1 & $4.36 \pm \mathrm{NA}$ & $8.4 \pm \mathrm{NA}$ & NA \\
\hline Harpalus (Metophonus) rufibarbis & winged & 7.9 & 1 & 1 & $0.78 \pm \mathrm{NA}$ & $3.8 \pm \mathrm{NA}$ & NA \\
\hline Harpalus laevipes & winged & 10.7 & 41 & 8 & $1.54 \pm 1.05$ & $4.4 \pm 1.01$ & 3.39 \\
\hline Harpalus latus & winged & 9.4 & 19 & 4 & $1.87 \pm 1.13$ & $4.3 \pm 1.83$ & 6.49 \\
\hline Harpalus rufipes & winged & 13.5 & 8 & 7 & $2.38 \pm 0.67$ & $7.7 \pm 2.01$ & 4.81 \\
\hline Harpalus tardus & winged & 9.6 & 9 & 2 & $1.83 \pm 1.30$ & $5.0 \pm 1.21$ & 3.52 \\
\hline Harpalus xanthopus winkleri & winged & 7.5 & 9 & 2 & $1.48 \pm 0.66$ & $3.1 \pm 1.45$ & 3.09 \\
\hline Leistus rufomarginatus & winged & 8.4 & 1 & 1 & $2.37 \pm \mathrm{NA}$ & $3.2 \pm \mathrm{NA}$ & NA \\
\hline Leistus termitus & winged & 6.0 & 16 & 5 & $2.33 \pm 0.34$ & $2.6 \pm 0.76$ & 1.20 \\
\hline Loricera pilicornis & winged & 6.9 & 2 & 2 & $1.20 \pm 1.93$ & $4.0 \pm 1.58$ & NA \\
\hline Nebria brevicollis & winged & 11.4 & 7 & 4 & $3.01 \pm 0.84$ & $6.8 \pm 0.79$ & 2.21 \\
\hline Notiophilus biguttatus & dimorphic & 4.4 & 4 & 2 & $3.52 \pm 0.15$ & $4.5 \pm 1.06$ & NA \\
\hline Notiophilus palustris & dimorphic & 4.7 & 13 & 7 & $2.93 \pm 0.34$ & $3.7 \pm 0.89$ & 1.51 \\
\hline Odacantha melanura & winged & 6.8 & 1 & 1 & $1.46 \pm \mathrm{NA}$ & $9.2 \pm \mathrm{NA}$ & NA \\
\hline Oodes helopioides & winged & 8.4 & 4 & 4 & $2.11 \pm 0.85$ & $6.3 \pm 1.12$ & NA \\
\hline Panagaeus cruxmajor & winged & 8.2 & 3 & 2 & $1.80 \pm 0.54$ & $2.4 \pm 0.07$ & NA \\
\hline Patrobus atrorufus & wingless & 8.2 & 16 & 5 & $2.86 \pm 0.49$ & $6.7 \pm 1.23$ & 2.18 \\
\hline Pterostichus aethiops & wingless & 13.2 & 4 & 2 & $3.17 \pm 0.50$ & $6.3 \pm 0.86$ & NA \\
\hline Pterostichus anthracinus & dimorphic & 10.7 & 5 & 2 & $3.05 \pm 0.46$ & $7.7 \pm 0.85$ & 2.22 \\
\hline Pterostichus diligens & dimorphic & 5.2 & 17 & 7 & $3.25 \pm 0.53$ & $6.9 \pm 1.43$ & 2.74 \\
\hline Pterostichus gracilis & winged & 9.2 & 3 & 2 & $2.95 \pm 0.42$ & $6.9 \pm 0.50$ & NA \\
\hline Pterostichus melanarius & dimorphic & 14.9 & 135 & 17 & $3.53 \pm 0.69$ & $7.2 \pm 1.29$ & 2.61 \\
\hline Pterostichus minor & dimorphic & 7.1 & 19 & 8 & $2.73 \pm 0.57$ & $6.9 \pm 0.72$ & 1.55 \\
\hline Pterostichus niger & winged & 17.7 & 99 & 13 & $1.62 \pm 0.76$ & $6.8 \pm 1.18$ & 2.83 \\
\hline Pterostichus nigrita & winged & 10.1 & 19 & 8 & $2.73 \pm 0.47$ & $7.5 \pm 1.64$ & 2.86 \\
\hline Pterostichus oblongopunctatus & winged & 10.4 & 69 & 16 & $2.02 \pm 0.87$ & $6.6 \pm 1.36$ & 3.77 \\
\hline Pterostichus strenuus & dimorphic & 5.9 & 67 & 13 & $3.12 \pm 0.59$ & $6.7 \pm 1.20$ & 2.25 \\
\hline Pterostichus vernalis & dimorphic & 6.6 & 50 & 10 & $2.99 \pm 0.41$ & $7.4 \pm 0.94$ & 1.32 \\
\hline Pterostichus (Poecilus) versicolor & winged & 10.0 & 7 & 2 & $1.71 \pm 0.68$ & $6.5 \pm 1.90$ & 4.80 \\
\hline Stomis pumicatus & wingless & 7.3 & 19 & 6 & $2.47 \pm 0.58$ & $7.6 \pm 1.02$ & 2.12 \\
\hline Syntomus truncatellus & dimorphic & 2.9 & 1 & 1 & $2.66 \pm \mathrm{NA}$ & $6.5 \pm \mathrm{NA}$ & NA \\
\hline Synuchus vivalis & dimorphic & 7.3 & 11 & 5 & $3.11 \pm 0.73$ & $6.8 \pm 0.75$ & 2.14 \\
\hline
\end{tabular}

